\title{
Spatial variability of particle size fractions of an Oxisol cultivated with conilon coffee
}

\author{
Julião Soares de Souza Lima ${ }^{1}$, Rone Batista de Oliveira², Samuel de Assis Silva ${ }^{3}$
}

\begin{abstract}
Information on the spatial distribution of particle size fractions is essential for use planning and management of soils. The aim of this work to was to study the spatial variability of particle size fractions of a Typic Hapludox cultivated with conilon coffee. The soil samples were collected at depths of $0-0.20$ and $0.20-0.40 \mathrm{~m}$ in the coffee canopy projection, totaling 109 georeferentiated points. At the depth of 0.2-0.4 m the clay fraction showed average value significantly higher, while the sand fraction showed was higher in the depth of 0-0.20 m. The silt showed no significant difference between the two depths. The particle size fractions showed medium and high spatial variability. The levels of total sand and clay have positive and negative correlation, respectively, with the altitude of the sampling points, indicating the influence of landscape configuration.
\end{abstract}

Key words: geostatistic, soil management, erosion.

\section{RESUMO}

\section{Variabilidade espacial das frações granulométricas de um latossolo Vermelho - Amarelo cultivado com café conilon}

O conhecimento da distribuição espacial das frações granulométricas é fundamental para o planejamento de uso e manejo do solo. Este trabalho teve como objetivo estudar, em duas profundidades, a variabilidade espacial das frações granulométricas de um Latossolo Vermelho-Amarelo distrófico sob cultivo de café conilon. As amostras de solo foram coletadas nas profundidades de 0-0,20 m e 0,20-0,40 m, na projeção da copa do cafeeiro, em uma malha irregular, totalizando 109 pontos georreferenciados. A fração argila apresentou o maior valor médio na profundidade de $0,20-0,40$ $\mathrm{m}$, enquanto, a fração areia total, na profundidade de 0-0,20 m. O silte não apresentou diferença significativa entre as duas profundidades avaliadas. As frações granulométricas apresentaram de baixa a média variabilidade espacial. Os teores de areia total e de argila apresentam correlação negativa e positiva, respectivamente, com a altitude dos pontos de amostragem, mostrando a influência da configuração da paisagem.

Palavras-chave: geoestatística, manejo do solo, erosão.

\footnotetext{
Received for publication on May 11th,2012 and accepted on October 10th, 2012.

${ }^{1}$ Agricultural Engineer, Doctor. Departamento de Engenharia Rural, Universidade Federal do Espírito Santo, Campus Alegre, Bairro Universitário, s/n, 29500-000, Alegre, Espírito Santo, Brasil. limajss@yahoo.com.br (autor para correspondência).

${ }^{2}$ Agronomist, Doctor. Instituto de Ciências Exatas, Universidade Paranaense, Campus 1, Praça Mascarenhas de Moraes, 4282, 87505-090, Umuarama, Paraná, Brasil. ronebatista@hotmail.com

${ }^{3}$ Agronomist, Master of Science. Doutorando do Departamento de Engenharia Agrícola, Universidade Federal de Viçosa, Campus Viçosa, Avenida Peter Henry Rolfs, s/n, 36570-000, Viçosa, Minas Gerais, Brasil. samuel-assis@hotmail.com
} 


\section{INTRODUCTION}

Variability in soil particle size fractions directly influences the surface flow and water movement in the soil, erosion, cation exchange capacity and retention of water and nutrients, which makes the knowledge on these properties fundamental for a better use planning and soil management. According to Vieira et al. (1988), other characteristics, such as infiltration, permeability to roots and aeration are also greatly influenced by the soil texture.

The slope and shape of the relief significantly influence the spatial distribution of soil attributes (Souza, 2001). Thus, in areas with mountainous terrain, different zones of management usually have close correlation with these factors, especially when considering development and productivity of the crops.

According to Souza (2001), the evolution of the slope is associated with erosion caused by runoff of rainwater, forming one of the most important physical agents in the configuration of the terrestrial landscape. Because the effects of the erosion can be dominant over the others, in the formation of the soil features, and this occurs in different directions and senses, its effect can be seen on the surface and/or in depth, changing the distribution of the attributes throughout the soil profile.

The availability of nutrients to plants is related to the replacement process, the soil texture, which allows greater or lesser mobility of some nutrients, and soil loss in the erosion process. According to Silva et al. (2010), knowing the spatial distribution of particle size fractions in areas cultivated with coffee will allow us to infer the availability of the chemical elements in the soil. The same authors, assessing the relationship between the texture of a humic Oxisol and the mineral nutrients from the soil, found a negative correlation of potassium $(\mathrm{K})$ with the total sand fraction and positive correlation for magnesium (Mg) with silt.

According to Campos et al. (2007), in areas with soils apparently homogeneous in a single soil class, using landscape models and geostatistics, one can capture spatial dependence of texture attributes in short distances, sufficient to interfere with crop productivity.

Several studies have shown that the physical and chemical attributes of the soil, as well as those relating to plants, exhibit spatial variability and that the distance between samples must be taken into account in the study of these attributes, as prescribed by the geostatistics (Vieira, 2000). According to Corá et al. (2004), management can change the soil attributes, affecting mostly the upper layers, even in areas that are identical from the pedological point of view.

In this context, this work aimed to study the spatial variability of particle size fractions of an Oxisol under conilon coffee, at two depths, using classical statistics and geostatistics.

\section{MATERIAL AND METHODS}

The study was conducted in an experimental area cultivated with conilon coffee, located in the southern Espirito Santo State, Brazil, 20 45'17,31" South latitude and $41^{\circ} 17^{\prime} 8,86^{\prime}$ west longitude, average altitude of $113 \mathrm{~m}$ and $16 \%$ slope. The climate, according to the classification of Koppen, is Cwa type, with poorly distributed rainfall throughout the year, with rainy summers and dry winters.

The study area is located in the upper third and middle third of a rounded hill with convex side slope, and the soil is classified as dystrophic clayey Oxisol (Embrapa, 2006).

Samples were taken on a irregular grid in an area of 1.0 ha, containing 109 sample georeferenced points, using a surveying GPS. The soil samples were taken in the projection of plant canopy, in the layers $0-0.20 \mathrm{~m}$ and 0.20 $0.40 \mathrm{~m}$.

After sampling, the soil was air dried, passed through a sieve of $2 \mathrm{~mm}$ and transformed into fine air-dried soil (TFSA). The determination of particle size fractions (clay, silt and total sand) was performed by slow agitation, followed by sedimentation assay in test tubes, according to Stokes law, following the methodology of Embrapa (1997).

For the identification and elimination of outliers in the data set, we used the boxplot tool that considers the interquartile range for setting those values. After this procedure, the data were analyzed by descriptive statistical analysis.

The verification of the normality of the data was performed by the Shapiro-Wilk's test $(\mathrm{p} \leq 0.05)$. We performed a Pearson correlation analysis $(\mathrm{p} \leq 0.05)$ between the values found for the fractions and the altitude of the sampling points in order to evaluate the effect of land slope on the distribution of fractions. A qualitative analysis using the Student $t$ test $(\mathrm{p} \leq 0.05)$ was performed to verify whether the average values of the fractions differ between the depths studied.

The tendency of the distribution of fractions in relation to north-south and east-west was analyzed by constructing scatterplots, and when significant, it was removed by fitting a polynomial of the first degree, for the fraction values, as a function of the coordinates, and the residue was obtained by subtracting the measured value from the value of the polynomial at each point, to meet the minimum stationarity required to using geostatistics, as described in Gonçalves et al. (2001).

The geostatistical analysis was performed to determine the existence of the spatial dependency of each soil fraction, by determining the classical experimental variogram of Matheron, using the software GS + (Robertson, 1998).

In the setting of variograms for each particle size fraction, the following parameters were determined: 
nugget effect $\left(\mathrm{C}_{0}\right)$, sill $\left(\mathrm{C}_{0}+\mathrm{C}\right)$ and range of spatial dependence (a). The choice of the model was based on the results of the cross validation, given by the correlation of the observed value with the estimated value at each sampling point. To determine the spatial dependence index (SDI), we used the ratio $\mathrm{C}_{0} /(\mathrm{C} 0+\mathrm{C})$, according to criteria established by Cambardella et al. (1994), who considered the weak spatial dependence (IDE $>75 \%)$, moderate $(25 \%$ $\leq 75 \% \leq \mathrm{IDE}$ ) and strong (IDE <25\%).

To facilitate interpretation and comparisons between the parameters, the variograms were scaled by dividing the semivariance by the variance of the data, as in Vieira et al. (1988).

Knowing the theoretical variograms, interpolation was done by the method of ordinary kriging to estimate values at unsampled locations and construction of thematic maps.

\section{RESULTS AND DISCUSSION}

The analysis of the outliers in the data set, in the layers $0-0.20 \mathrm{~m}$ and $0.20-0.40 \mathrm{~m}$, is shown in Figure 1 .

All the fractions present in the two depths showed unilateral outliers, except for the silt layer 0-0.20 m (Sil1), which showed bilateral points. Clay presented, at both depths, values below the range of distribution, while the total sand had values above this range. After further analysis of the samples at the points that indicated the outliers, and when confirmed their presence, were removed for performing the descriptive analysis of the data and also the t-test $(\mathrm{p}<0.05)$ between the means at both depths (Table 1 ) in order to not compromise the geostatistical analysis.

The attributes clay and silt at a depth of $0-0.20 \mathrm{~m}$, and silt at $0.20-0.40 \mathrm{~m}$, had normal distribution $(\mathrm{p} \leq 0.05)$. The coefficient of asymmetry $(\mathrm{Cs})$ and kurtosis $(\mathrm{Ck})$ near zero for these attributes data confirm the trend to normality, although the occurrence of non-normality is common for data obtained from nature (Webster, 1985).

The clay (0.20-0.40 m) and the total sand (0 to $0.20 \mathrm{~m}$ and $0.20-0.40 \mathrm{~m}$ ) had non-normal distribution; but the tail of the distribution was not too elongated, which does not limit the use of geostatistical analysis. Simões et al. (2006), in an Oxisol, Lima et al. (2007), in a dystrophic Oxisol and Lima et al. (2009), in an Ultisol, found normality for all size fractions.

According to the classification proposed by Warrick \& Nielsen (1980), except for clay (0.20-0.40 m) with low CV (less than 12\%), other size fractions showed average CV (between 12 and 60\%). Overall, these variabilities are close to those found by Lima et al. (2009) in areas cultivated with pasture and natural vegetation in Ultisol.

Pocay (2000) discussed that the total sand fraction in Oxisols is one of the most stable features of soil, ie, it modifies slightly over time by the action of weathering, thus, it has an average range of values, regardless of the depths. The silt at both depths showed the highest CVs. This variation may be related to its determination process in the laboratory, as the clay is separated by sedimentation and silt determined by difference and may be incorporated, thus, being part of the variability of total sand and clay fractions.

The clay was positively correlated with altitude of the sampling points (42 and 51\%), in the layers $0-0.20 \mathrm{~m}$ and 0.20-0.40 m, respectively, confirming the highest concentration in the upper third. In correlation analysis of total sand with the altitude of sampling points were obtained $-55 \%$ and $-27 \%$ for $0-0.20 \mathrm{~m}$ and $0.20-0.40 \mathrm{~m}$, respectively. Negative correlation was also detected by

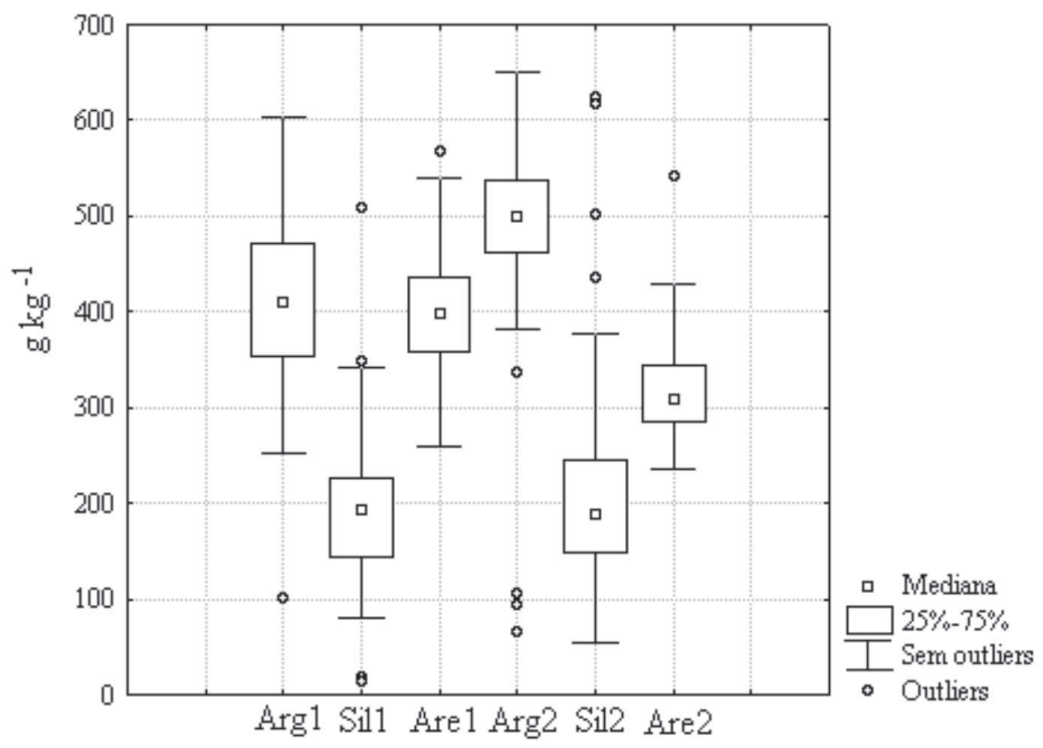

Figure 1. Boxplot of size fractions at two depths: clay: Arg1 (0-0.20 m) and Arg2 (0.20-0.40 m), silt: Sil1 (0-0.20 m) and Sil2 (0.20 $-0.40 \mathrm{~m})$ and total sand: Are1 (0-0.20 m) and Are2 (0.20-0.40 m). 
Torrado (1989) and Lima et al. (2009) for the total sand fraction, in pasture and natural vegetation and also by Ortiz (2003), in stands of eucalypts grown in sloppy area. The authors claim that this is due to erosion as a result of runoff, which, over the years, favors the transport and accumulation of larger and heavier particles on the lower levels of the ground during the rainy season and removal of smaller particles from the area.

The trend of concentration of soil size fractions in relation to the positions of the sampling area was analyzed. In the north-south direction, the attributes silt $(0-0.20 \mathrm{~m})$ and total sand $(0.20-0.40 \mathrm{~m})$ showed no trend and only the total sand $(0-0.20 \mathrm{~m})$ tended toward east-west. Considering this, it was used the residues of the multiple linear regression of the fraction relative to the local coordinates, since according to Gonçalves et al. (2001), the presence of trend in attributes could compromise the geostatistical analysis.

The clay and total sand at the two depths exhibited spatial dependence (Table 2), with $\mathrm{R}^{2}$ greater than $89.0 \%$ of the variogram fit, indicating that the variability in the estimated values of semivariance is explained by the fitted models. For the clay, at the depths of $0-0.20$ and $0.20-0.40 \mathrm{~m}$, and total sand at $0.20-0.40 \mathrm{~m}$, the spherical model was adjusted, and the Gaussian model was ajusted for the total sand at $0-0.20 \mathrm{~m}$. Souza et al. (2004) found that the spherical model fit for the fractions of an Oxisol.
The silt showed no spatial dependence, as found by Silva et al. (2007) and Lima et al. (2007), in Oxisol, allowing to conclude that in the scale of soil sampling, its distribution is presented independently in the space, i.e., considered random for distances greater than the smallest distance used in the experiment.

The spatial dependence index (IDE) was moderate, compared to the total variance, with values ranging from 37 to $50 \%$ at both depths. Cross-validation was significant for the correlation between observed and estimated values based on fit models of the variograms chosen (Table 2).

The range of spatial dependence for the clay was 41.0 $\mathrm{m}$ and $47.0 \mathrm{~m}$, in the layers $0-0.20 \mathrm{~m}$ and $0.20-0.40 \mathrm{~m}$, respectively, showing the same pattern of spatial distribution, while the total sand presented ranges with values of $54.0 \mathrm{~m}$ and $12.0 \mathrm{~m}$, in the layers $0-0.20 \mathrm{~m}$ and 0.20-0.40 m, respectively. This means that samples separated by distances smaller than the range are correlated to each other, which allows interpolations are carried out for values of spacings smaller than those used in the sampling. Trangmar et al. (1985) argue that the range defines the maximum radius for which the neighboring samples are used for interpolation by kriging. In this case, lower ranges may influence the estimation of unsampled values.

The difference between the ranges for the total sand between depths was reported by Souza et al. (2004), who

Table 1. Descriptive statistics of the soil size fractions $\left(\mathrm{g} \mathrm{kg}^{-1}\right)$ and t-test between means at the layers $0-0.20 \mathrm{~m}$ and $0.20-0.40 \mathrm{~m}$

\begin{tabular}{|c|c|c|c|c|c|c|c|c|c|}
\hline \multirow{2}{*}{ Fractions } & \multirow{2}{*}{ Mean } & \multirow{2}{*}{ Md } & \multirow{2}{*}{$\mathbf{s}$} & \multicolumn{2}{|c|}{ Values } & \multicolumn{3}{|c|}{ Coefficients } & \multirow{2}{*}{ DN } \\
\hline & & & & Minimum & Maximum & $\mathrm{CV}$ & $\mathrm{C}_{\mathrm{s}}$ & $\mathrm{C}_{\mathrm{k}}$ & \\
\hline$\overline{\text { Clay }^{1}}$ & $416.4 b$ & 411.9 & 78.6 & 251.7 & 602.8 & 18.9 & 0.06 & -0.52 & ns \\
\hline Clay $^{2}$ & $495.8 \mathrm{a}$ & 499.0 & 55.4 & 336.0 & 622.0 & 11.2 & -0.22 & -0.04 & $*$ \\
\hline Silt $^{1}$ & $192.9 \mathrm{a}$ & 195.6 & 57.0 & 89.8 & 348.4 & 29.6 & -0.50 & -0.07 & ns \\
\hline Silt $^{2}$ & $195.6 \mathrm{a}$ & 188.4 & 57.7 & 103.2 & 378.0 & 29.5 & 0.55 & 0.00 & ns \\
\hline Total sand ${ }^{1}$ & $397.4 \mathrm{a}$ & 397.4 & 59.2 & 259.8 & 540.0 & 14.9 & -0.08 & -0.27 & $*$ \\
\hline Total sand ${ }^{2}$ & $315.7 \mathrm{~b}$ & 309.3 & 48.1 & 235.5 & 542.7 & 15.3 & 1.14 & 3.61 & $*$ \\
\hline
\end{tabular}

${ }^{1}$ attributes in the depth of $0-0.20 \mathrm{~m} ;{ }^{2}$ attributes in the depth of 0.20-0.40 m; Md - median; s - standard deviation; CV - coefficient of variation; $\mathrm{C}_{\mathrm{s}}$ - Coefficient of asymmetry; $\mathrm{C}_{\mathrm{k}}$ - coefficient kurtosis; * - non-normal distribution, and ns - normal distribution by the ShapiroWilk's test $(\mathrm{p} \leq 0.05)$. For the same attribute, means followed by the same small letter in the column are not significantly different by $\mathrm{t}$ test $(\mathrm{p} \leq 0.05)$

Table 2. Variogram parameters scaled adjusted for the soil attributes in the layers $0-0.20 \mathrm{~m}$ and $0.20-0.40 \mathrm{~m}$

\begin{tabular}{lccccccc}
\hline Attributes & Model & $\mathbf{A}(\mathbf{m})$ & $\mathbf{C}_{\mathbf{0}}$ & $\mathbf{C}_{\mathbf{0}}+\mathbf{C}$ & $\mathbf{I D E}(\boldsymbol{\%})$ & $\mathbf{R}^{2}(\boldsymbol{\%})$ & VC \\
\hline Clay $^{1}$ & ESF & 41.00 & 0.54 & 1.09 & 50.00 & 89.00 & $*$ \\
Clay $^{2}$ & ESF & 47.00 & 0.56 & 1.15 & 49.00 & 92.00 & $*$ \\
Silt $^{1}$ & EPP & 0.00 & 0.95 & 0.95 & - & - & - \\
Silt $^{2}$ & EPP & 0.00 & 1.00 & 1.00 & - & - & - \\
Total sand $^{1}$ & GAU & 54.00 & 0.55 & 1.28 & 37.00 & 93.00 & $*$ \\
Total sand $^{2}$ & ESF & 12.00 & 0.12 & 1.02 & 40.00 & 90.00 & $*$ \\
\hline
\end{tabular}

${ }^{1}$ attributes in the 0-0.20 m depth; ${ }^{2}$ attributes in the depth of 0.20-0.40 m; ESF-spherical model; EPP - pure nugget effect; GAU-Gaussian; $\mathrm{C}_{0}$ - nugget effect; $\mathrm{C}_{0}+\mathrm{C}$ - sill; IDE - index of spatial dependence $\left(\mathrm{C} /\left(\mathrm{C}_{0}+\mathrm{C}\right)\right)$; a - range; $\mathrm{R}^{2}$ - coefficient of determination of the semivariogram model; and $\mathrm{VC}(*)$ - significant between observed and predicted values by cross-validation. 
discussed that in deeper layers the soil fractions have greater discontinuity, that is, with smaller ranges, which is related to the little action of weathering in depth. Corá et al. (2004) stated that the soil management, carried out in an area, over time, can contribute to greater homogenization of the surface layer, and, consequently, increase the range of spatial dependency of soil properties, which limits a greater continuity in the spatial distribution in this layer in relation to the deeper layer. Furthermore, Fields et al. (2007) pointed out that the actual relief variation significantly influences the determination of the transport and deposition of sediments, so as to cause spatial variability in soil attributes.

According to the parameters and models of the variogram defined, values for the soil fractions were estimated by ordinary kriging at locations that were not measured (Figure 2). It is seen that, considering the same scale and the same fraction, at different depths, the total sand has a higher concentration in the lower portion of the area, at a depth of 0-0.20 m, northward, and the clay had the highest concentration in the upper portion, toward the south, at a depth of $0.20-0.40 \mathrm{~m}$, according to the correlation with altitude, discussed earlier. (Figure 2)

The average total sand fraction $\left(397.4 \mathrm{~g} \mathrm{~kg}^{-1}\right)$ in the area $(0-0.20 \mathrm{~m})$ is in the range $360-420 \mathrm{~g} \mathrm{~kg}^{-1}$, indicating a more continuous region, as a function of the greater range of spatial dependence $(54.0 \mathrm{~m})$. The lowest range $(12.0$ $\mathrm{m})$ is reflected by the discontinuity in the region between 300 and $360 \mathrm{~g} \mathrm{~kg}^{-1}$, indicating a more random distribution, with the average value of $315.7 \mathrm{~g} \mathrm{~kg}^{-1}$. Similar spatial distribution pattern can be seen in the clay fraction, the region with the greatest concentration of values in the upper portion of the area.

Spatial analysis allows for a more complete interpretation of the distribution of particle size fractions, in the area cultivated with coffee, and also shows the size of fractions between the depths studied. In addition, it enables to realize the negative spatial correlation between the clay and total sand fractions for the soil under study, complementing the analysis by classical statistics.
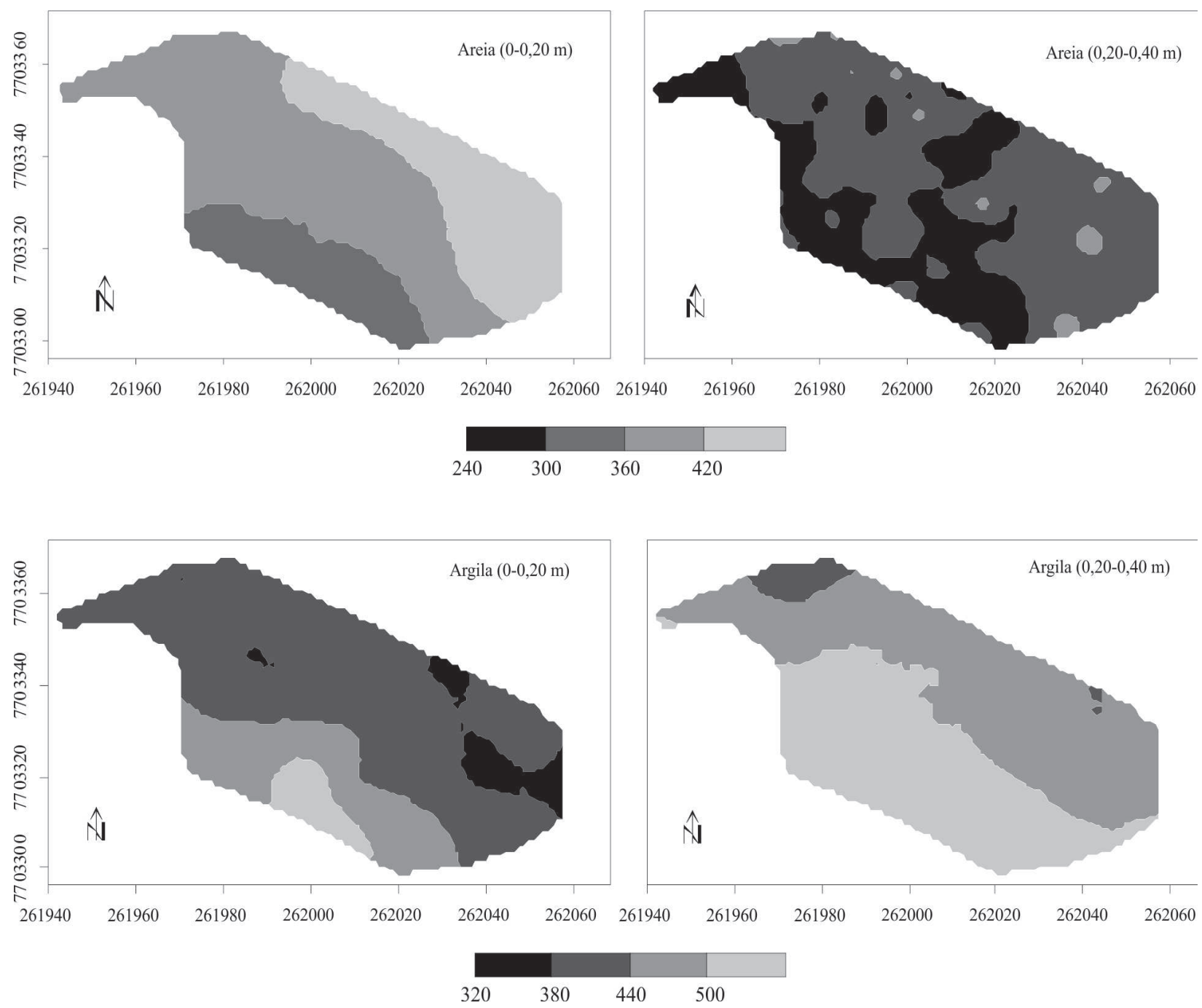

Figure 2. Thematic maps of clay and total sand size fractions in the layers $0-0.20 \mathrm{~m}$ and $0.20-0.40 \mathrm{~m}$. 


\section{CONCLUSIONS}

The size fractions have low to medium variability in the area.

All fractions exhibit spatial dependence at both depths, with the exception of silt, by relating the spatial continuity of fractions with the depth of soil sampling.

The levels of total sand and clay have negative and positive correlations, respectively, with the altitude of the sampling points, showing the influence of the landscape.

\section{ACKNOWLEDGMENTS}

The authors thank CNPq for the productivity scholarship granted to the first author, and FAPES for the resources for the research.

\section{REFERENCES}

Cambardella CA, Moorman TB, Novack JM, Parkin TB, Karlen DL, Turco RF \& Knopka AE (1994) Field-scale variability of soil proprieties in central Iowa soils. Soil Science Society America Journal, 58:1240-1248.

Campos MCC, Marques Junior J, Pereira GT, Montanari R \& Siqueira DS (2007) Variabilidade espacial da textura de solos de diferentes materiais de origem em Pereira Barreto. Revista Ciências Agronômicas, 38:149-157.

Corá JE, Araujo AV, Pereira GT \& Beraldo JMG (2004) Variabilidade espacial de atributos do solo para adoção do sistema de agricultura de precisão na cultura de cana-de-açúcar. Revista Brasileira Ciências do Solo, 28:1013-1021.

Empresa Brasileira de Pesquisa Agropecuária - Embrapa (1997) Manual de métodos de análise de solo. $2^{\mathrm{a}}$ ed. Rio de Janeiro, Ministério da Agricultura e do Abastecimento. 212p.

Empresa Brasileira de Pesquisa Agropecuária - Embrapa (2006) Centro Nacional de Pesquisa de Solos. Sistema brasileiro de classificação de solos. $2^{\mathrm{a}}$ ed. Rio de Janeiro, Embrapa solos. 306p.

Gonçalves ACA, Folegatti MV \& Mata JDV (2001) Análise exploratória e geoestatística da variabilidade de propriedades físicas de um Argissolo Vermelho. Acta Scientiarum, 23:11491157.

Lima JSS, Oliveira RB \& Quartezani WZ (2007) Variabilidade espacial de atributos físicos de um Latossolo Vermelho-Amarelo sob cultivo de pimenta-do-reino. Engenharia na Agricultura, 15:290-298.

Lima JSS, Sattler MA, Xavier AC, Passos RR \& Oliveira PC (2009) Variabilidade espacial da textura de um Argissolo VermelhoAmarelo sob cultivo de pastagem e vegetação nativa. Ciência Rural, 39:2634-2637.

Ortiz JL (2003) Emprego do geoprocessamento no estudo da relação entre potencial produtivo de um povoamento de eucalipto e atributos do solo e do relevo. Dissertação de Mestrado. Escola Superior de Agricultura "Luiz de Queiroz", Piracicaba. 205p.

Pocay VG (2000) Relações entre pedoforma e variabilidade espacial de atributos de latossolos sob cultivo de cana-de-açúcar. Dissertação de Mestrado. Universidade Estadual Paulista, Jaboticabal. 177p.

Robertson GP (1998) GS+: Geoestatistics for the environmental sciences - GS+ User's Guide. Plainwell, Gamma Desing Software. $152 \mathrm{p}$.

Rev. Ceres, Viçosa, v. 59, n.6, p. 867-872, nov/dez, 2012
Silva SA, Lima JSS, Oliveira RB, Souza GS \& Silva MA (2007) Análise espacial da erosão hídrica em um Latossolo VermelhoAmarelo sob cultivo de café conilon. Revista Ciências Agronômicas, 38:335-342.

Silva SA, Lima JSS \& Souza GS (2010) Estudo da fertilidade de um Latossolo Vermelho-Amarelo húmico sob cultivo de café arábica por meio de geoestatística. Revista Ceres, 57:560-597.

Simões WL, Silva EL, Lima DM \& Oliveira MS (2006) Variabilidade espacial de atributos físicos de um Latossolo Vermelho distroférrico submetido a diferentes manejos. Revista Brasileira de Ciência do Solo, 30:1161-1068.

Souza CK (2001) Relação solo-paisagem-erosão e variabilidade espacial de Latossolos em áreas sob cultivo de cana-de-açúcar no município de Jaboticabal (SP). Dissertação de Mestrado. Universidade Estadual Paulista, Jaboticabal. 186p.

Souza ZM, Marques Junior J, Pereira GT \& Barbieri DM (2004) Variabilidade espacial da textura de um Latossolo VermelhoAmarelo eutroférrico sob cultivo de cana-de-açúcar. Engenharia Agrícola, 24:309-319.

Torrado PV (1989) Relações solo x relevo em Mococa (SP): Influência das características topográficas e posição na vertente nos atributos do solo. Dissertação de Mestrado. Escola Superior de Agricultura "Luiz de Queiroz", Piracicaba. 205p.

Trangmar BB, Yost RS \& Uehara G (1985) Application of geostatistics to spatial estudies of soil properties. Advances in Agronomy, 38:45-93.

Vieira LS, Santos PCTC \& Vieira MNS (1988) Solos: propriedade, classificação e manejo. Brasília, MEC/ABEAS. 154p. (Programa Agricultura nos Trópicos, v.2).

Vieira SR (2000) Geoestatística em estudos de variabilidade espacial do solo. In: Novais RF, Alvarez V VH \& Schaefer CEGR (Ed.) Tópicos em ciência do solo. Viçosa, Sociedade Brasileira de Ciência do Solo. p.01-54.

Warrick AW \& Nielsen DR (1980) Spatial variability of soil physical properties in the field. In: Hillel D (Ed.) Application of soil physics. New York, Academic Press. p.319-324.

Webster R (1985) Quantitative spatial analysis of soil in the field. In: Stewar TBA (Ed.) Advance in Soil Science. New York, Springer-Verlag. p.01-70. 